\title{
c-myc Gene Inactivation During Induced Maturation of HL-60 Cells Transcriptional Repression and Loss of a Specific DNAse I Hypersensitive Site
}

\author{
Katherine A. High, Catherine A. Stolle, Jay W. Schneider, Wendy Hu, and Edward J. Benz, Jr. \\ Departments of Medicine and Human Genetics, Yale University School of Medicine, New Haven, Connecticut 06510
}

\begin{abstract}
The c-myc proto-oncogene is amplified and expressed at high levels in HL-60 cells, a cell line derived from a patient with acute promyelocytic leukemia. Upon induction to terminal maturation, expression of c-myc is greatly reduced. We have studied the level of gene expression at which the change in c-myc expression is controlled and the changes in chromatin configuration that accompany the repression of myc expression. We report here that the repression of myc expression with induced maturation is controlled at the level of transcription, and that reduced expression is accompanied by the loss of a single DNAse I hypersensitive site 0.9 kilobase pair upstream from the gene.
\end{abstract}

\section{Introduction}

Differentiation and maturation of blood cells involve the enhanced transcription of a few genes whose products characterize the mature cell, and the concomitant orderly repression of the vast majority of the genome. To examine more closely the processes governing gene inactivation during cellular differentiation, we have studied changes in gene expression in a human leukemia cell line that can undergo terminal maturation under the influence of inducers.

HL-60 cells are a permanent cell line derived from a patient with acute promyelocytic leukemia (1). They undergo maturation along either a granulocytic pathway (following induction with, e.g., dimethyl sulfoxide or retinoic acid) or a macrophagemonocyte pathway (following induction with phorbol esters) (2, 3). Gallo et al. (4) have previously reported that expression of the c-myc proto-oncogene declines upon induction to terminal maturation. The c-myc proto-oncogene, which is homologous to the transforming DNA sequence of MC-29 avian myelocytomatosis virus (5), is amplified 16- to 32-fold in HL-60 cells (6). The gene is transcribed at high levels in uninduced HL-60, but expression of $c-m y c$ is greatly reduced after induction to terminal maturation (6).

In this communication, we describe experiments designed to determine the step in gene expression at which the change in

Portions of this work were presented at the 26th Annual Meeting of the American Society of Hematology, 1-4 December 1984, Miami Beach, FL.

Address reprint requests to Katherine A. High, M.D., Assistant Professor of Medicine and Pathology, School of Medicine, Department of Medicine, Hematology Division, University of North Carolina at Chapel Hill, 416 Burnett-Womack Clinical Sciences Building 229H, Chapel Hill, NC 27514.

Received for publication 19 February 1986.

J. Clin. Invest.

(c) The American Society for Clinical Investigation, Inc.

0021-9738/87/01/0093/07 \$1.00

Volume 79, January 1987, 93-99 c-myc expression is regulated and the changes in chromatin configuration that accompany the repression of myc expression. Our data show that the repression of $m y c$ upon induction to terminal maturation is controlled at the level of transcription, and that reduced expression is accompanied by the loss of a single DNAse I hypersensitive site 0.9 kilobase $(\mathrm{kb})$ upstream from the gene.

\section{Methods}

Cells. HL-60 cells (1) were grown in suspension culture in RPMI medium supplemented with $10 \% \mathrm{Nu}$ serum (Collaborative Research, Inc., Waltham, MA) and maintained at $37^{\circ} \mathrm{C}$ in a humidified atmosphere containing $5 \% \mathrm{CO}_{2}$. Inductions were carried out with $1 \%$ dimethyl sulfoxide (DMSO). Cells were harvested after $72 \mathrm{~h}$ induction.

Recombinant plasmids. Plasmid v-myc (a gift of Dr. Paul Lebowitz) contains a 2.9-kb gag-myc sequence inserted into pBR322. Plasmids pmycR1.3 and pmyc2.3 (gifts of Dr. G. Rovera) contain human c-myc cDNA sequences as described in reference 7. C6 1.8 BAM contains human beta globin sequence (8). Plasmid pJEM120 (a gift of James Metherall, Yale University) contains a 3.1-kb Eco RI fragment that includes repetitive Alu sequences from gamma globin-beta globin intergenic DNA. The gamma actin probe (a gift of Peter Gunning) consists of a 1-kb PstXba fragment of plasmid pHF-1 (9).

Cytoplasmic RNA preparation. Cytoplasmic RNA was prepared by the method of White and Bancroft (10). After lysis of washed cells and sedimentation of nuclei, the cytoplasm was denatured in $8 \%$ formaldehyde at $60^{\circ} \mathrm{C}$ for $15 \mathrm{~min}$, then directly dotted onto nitrocellulose for analysis by hybridization to clone ${ }^{32} \mathrm{P}$-labeled DNA probes. Prehybridization and hybridization of the nitrocellulose membranes were carried out by the method of Thomas (11).

In vitro transcription by isolated nuclei and isolation of ${ }^{32} P-R N A$. Nuclei were isolated from uninduced and dimethylsulfoxide-induced (DMSO) HL-60 cells by the procedure of Mory and Gefter (12). Transcription of nuclei and subsequent RNA isolation were performed essentially as described by Linial, Gunderson, and Groudine (13). Nuclei were incubated at $30^{\circ} \mathrm{C}$ for $30 \mathrm{~min}$, a time chosen to be linear with respect to alpha- $\left[{ }^{32} \mathrm{P}\right] U T \mathrm{P}$ incorporation in preliminary studies with these nuclei. The reactions were terminated by the addition of RQ1 DNAse (Promega Biotec, Madison, WI) to $10 \mu \mathrm{g} / \mathrm{ml}$ at $30^{\circ} \mathrm{C}$ for $5 \mathrm{~min}$. The RNA isolation procedure was exactly as described in reference 13.

Assay for specific RNA sequences. For detection of radioactive RNA transcripts, cloned DNAs were digested with appropriate restriction enzymes; the fragments of interest were then isolated by gel electrophoresis and applied to Nytran membranes with a slot blot apparatus (Schleicher and Schuell, Inc., Keene, NH). Prehybridization and hybridization of filters to radiolabeled RNA were carried out as described (13).

Determination of transcript stability. Intact HL-60 cells harvested before and after exposure to DMSO were incubated with actinomycin $\mathrm{D}(10 \mu \mathrm{g} / \mathrm{ml}) .3 \times 10^{7}$ cells were withdrawn immediately before and 15 , 45, and $90 \mathrm{~min}$ after addition of actinomycin D. Cytoplasmic extracts were prepared by the method of White and Bancroft (10), and hybridization to cloned ${ }^{32} \mathrm{P}$-labeled probes was carried out with the hybridization procedure of Thomas (11). In the induced cells, transcript stability was determined by the same technique $18 \mathrm{~h}$ after DMSO induction.

Limited DNAse I digestion of chromatin and blot hybridization. Nuclei were isolated by lysis of cells in hypotonic buffer (equal volume phosphate-buffered saline and $25 \mathrm{mM}$ Tris $\mathrm{HCl}$ [pH 7.4], $10 \mathrm{mM} \mathrm{MgCl}$ ) with $0.5 \%$ Triton X-100, in the presence of $0.5 \mathrm{mM}$ phenylmethyl sulfonyl 
fluoride. The nuclei were washed several times in the same buffer without Triton X-100, digested in buffer A (10 mM tris, pH 7.4, $10 \mathrm{mM} \mathrm{NaCl}$, $3 \mathrm{mM} \mathrm{MgCl}$ ) containing $0.05-12 \mu \mathrm{g} / \mathrm{ml}$ pancreatic deoxyribonuclease at a DNA concentration of $\sim 1 \mathrm{mg} / \mathrm{ml}$ at $37^{\circ} \mathrm{C}$ for $10 \mathrm{~min}$. Digestions were terminated by adding $\mathrm{Na}_{3}$ EDTA ( $\mathrm{pH} 8$ ) to a final concentration of $20 \mathrm{mM}$ and sodium dodecyl sulfate (SDS) to $0.5 \%$. Proteinase $\mathrm{K}$ was added to $100 \mu \mathrm{g} / \mathrm{ml}$. The preparations were incubated overnight at $37^{\circ} \mathrm{C}$ and then extracted with phenol/chloroform (14). Pancreatic RNAse was added to the aqueous phase at $50 \mu \mathrm{g} / \mathrm{ml}$. After incubation at $37^{\circ} \mathrm{C}$ for $2 \mathrm{~h}, \mathrm{SDS}(0.5 \%)$ and proteinase $\mathrm{K}(100 \mu \mathrm{g} / \mathrm{ml})$ were added, and the incubation was continued at $37^{\circ} \mathrm{C}$ for $2 \mathrm{~h}$ more. DNA was then recovered by phenol/chloroform extraction and ethanol precipitation.

Purified DNA was digested with restriction enzymes according to manufacturer's recommendations. The resulting DNA fragments were separated on $0.8-1 \%$ agarose gels and transferred to nitrocellulose filters (BA85; Schleicher and Schuell, Inc.) by the method of Southern (15). Hybridization to nick translated probes $\left(1-2 \times 10^{8} \mathrm{cpm} / \mu \mathrm{g}\right)(16)$ was carried out at $67^{\circ} \mathrm{C}$ overnight in $6 \times$ standard saline citrate (SSC), 10 mM EDTA, $100 \mathrm{mM} \mathrm{KPO}_{4}$, 5× Denhardt's solution, 0.5\% SDS, 0.25 $\mathrm{mg} / \mathrm{ml}$ denatured salmon sperm DNA with $50 \times 10^{6} \mathrm{cpm}$ nick-translated probe, after a 5-h prehybridization incubation in the same buffer minus the nick-translated probe. Filters were washed in $2 \times$ SSC, $0.5 \%$ SDS at room temperature (twice, for $15 \mathrm{~min}$ each) followed by $0.1 \times \mathrm{SSC}, 0.5 \%$ SDS at $67^{\circ} \mathrm{C}$ (twice, for $30 \mathrm{~min}$ each), and exposed at $-70^{\circ} \mathrm{C}$ with Lightning Plus intensifying screens (DuPont Co., Wilmington, DE). cDNA probes were used in these studies because they lack repetitive elements.

\section{Results}

Steady state levels of myc RNA decrease with induction to terminal maturation. To analyze c-myc gene behavior during $\mathrm{HL}$ 60 cell maturation, we first established that steady state levels of $c-m y c$ mRNA decline as a function of induction. These results are shown in Fig. 1. Wright's stains of uninduced and induced HL-60 cells show that the uninduced cells resemble blasts and promyelocytes (Fig. $1 A$ ), whereas the cells undergo maturation to more mature granulocytic precursors during DMSO induction
(Fig. 1 B). Upon induction, there was a marked decrease in steady state levels of $m y c$ RNA, as indicated by the dot blots of cytoplasm in Fig. $1 B$. The bottom panel shows RNA hybridizing to an Alu-reiterated sequence chosen to control for RNA recovery. Equal amounts of total RNA showed a dramatic decline in c-myc mRNA. Thus the decrease in myc mRNA is a specific consequence of induction.

Decrease in myc expression is regulated at the level of transcription. We reasoned that the decrease in steady state levels of myc mRNA after induction must result from either decreased synthesis (transcription) of mRNA, decreased or aberrant processing of the transcript, or decreased cytoplasmic mRNA stability. To assess these possibilities, two types of experiments were performed: "runoff" endogenous nuclear transcription, and measurement of myc mRNA stability.

Runoff endogenous nuclear transcription allowed us to determine changes in the rate of synthesis of c-myc transcripts as a function of induction. In isolated nuclei, previously initiated RNA polymerase II transcripts elongate, but do not reinitiate, when given a source of nucleotide triphosphates. For our experiments, incubations were conducted in the presence of $\left[{ }^{32}\right.$ P]UTP to allow generation of radiolabeled transcripts. The radiolabeled RNA was then isolated and hybridized to specific DNA sequences bound to nylon membranes. The amount of radioactivity hybridizing to c-myc-specific DNA fragments reflects the number of RNA polymerase II molecules engaged in transcription of the c-myc gene.

We used runoff transcription to examine the overall transcription rates in uninduced and DMSO-induced HL-60 cells, and to determine the effect of induction on c-myc transcription rates. Total RNA synthesis (incorporation of $\left[{ }^{32} \mathrm{P}\right] \mathrm{UTP}$ into TCA-precipitable product) proceeded at a linear rate for about 20-30 min, and then at a reduced rate for the ensuing $30 \mathrm{~min}$ (data not shown). The total amount of mRNA produced by induced nuclei after $20 \mathrm{~min}$ was $\sim$ three-fold lower than the
A

\section{PREINDUCTION}

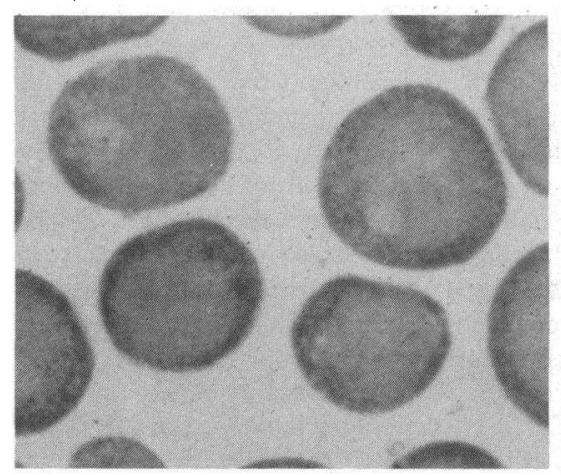

Dilution Factor

mRNA

$\quad 1: 1 \quad 1: 2 \quad 1: 4$

c-myc

"Blur 8" (AluI)
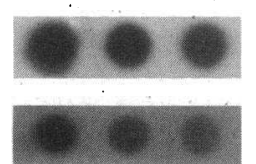

B

\section{POSTINDUCTION}

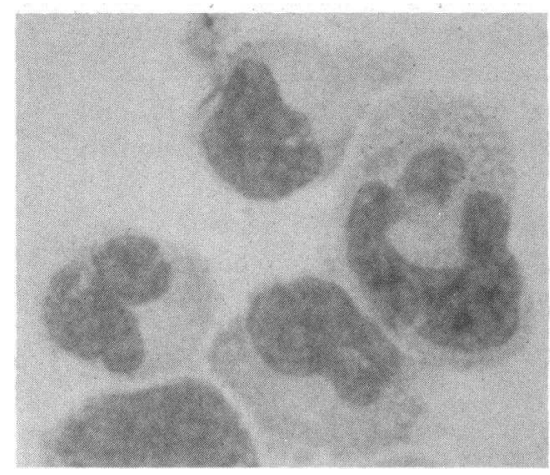

Dilution Factor

$\begin{array}{lll}1: 1 & 1: 2 & 1: 4\end{array}$

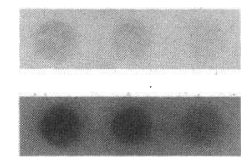

Figure 1. Effect of induction on cytoplasmic mRNA accumulation in HL-60 cells. Wright stains show HL-60 morphology before $(A)$ and $72 \mathrm{~h}$ after $(B)$ induction with $1 \%$ DMSO. Under these conditions, DMSO induces $\sim 80 \%$ of cells; note persistence of blast form in lower left hand corner $(B)$. Cytoplasmic dot blots (shown beneath Wright stains) prepared from $2 \times 10^{7}$ HL-60 cells show marked decline in $m y c$ mRNA with induction to terminal maturation, while Alu transcripts remain unchanged. 
amount produced by uninduced cells. This decrease in overall rate of transcription after induction was a highly reproducible effect. Generally the overall rate of transcription in the induced nuclei was $\sim 30 \%$ of that in uninduced nuclei.

To assess transcription of the c-myc gene, we isolated radiolabeled RNA from equal numbers of induced and uninduced HL-60 nuclei after $30 \mathrm{~min}$ of incubation with $\left[{ }^{32} \mathrm{P}\right] \mathrm{UTP}$. The RNA was hybridized to cloned DNA fragments immobilized on nylon membranes. Fig. 2 shows the results of hybridization of the labeled ${ }^{32} \mathrm{P}$ RNA to a 2.9-kb v-myc fragment. In the uninduced cells, rate of c-myc transcription was high, whereas in the induced cells, myc transcripts were barely detectable. Hybridization to an Alu sequence documents that the overall decrease in rate of transcription does not affect recovery of Pol III transcripts. Hybridization to a $1.5-\mathrm{kb}$ globin fragment gave no signal in either case, thus ruling out nonspecific binding. Finally, hybridization to an actin gene sequence documents that the dramatic decrease in rate of $c-m y c$ transcription is specific; it does not occur with other Pol II transcripts.

Densitometer tracings of the autoradiograms (Fig. 3) obtained from several experiments showed at least 14-fold reduction in c-myc mRNA after DMSO induction. Reduced c-myc expression after induction thus appears to be selective in that it is more marked than the overall decline in mRNA production.

Myc $m R N A$ is equally unstable in induced and uninduced $H L-60$ cells. The quantitative decrease in c-myc transcription demonstrated in the runoff assays fully accounts for the change in steady state levels of c-myc mRNA after induction. Nonetheless, we also studied the turnover of c-myc mRNA to determine whether stability of mRNA transcripts changed after induction. Total cytoplasmic RNA was extracted from HL-60 cells before, and at various times after, treatment with actinomycin $\mathrm{D}$ in doses $(10 \mu \mathrm{g} / \mathrm{ml})$ sufficient to block virtually all transcriptional activity. The cytoplasmic extracts were spotted onto nitrocellulose and hybridized to a nick-translated v-myc probe. Fig. 4 shows that myc mRNA levels decline rapidly (within 20 $\mathrm{min}$ ) in uninduced HL-60 cells following addition of actinomycin D. The fact that $m y c$ transcripts have such short half-lives in uninduced cells renders unlikely any possibility that further destabilization could add appreciably to the rapidity of decrease in steady state levels seen in induced cells. Nevertheless, these experiments were carried out under the following conditions: at $72 \mathrm{~h}$ post-DMSO induction, c-myc expression is so reduced that

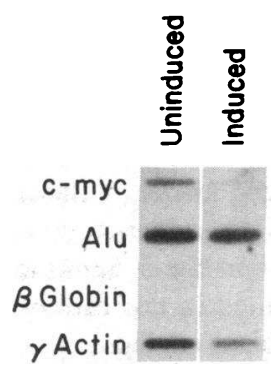

Figure 2. c-myc RNA synthesis in nuclei isolated from control and DMSO-induced HL60 cells. Nuclei from $4.2 \times 10^{7}$ cells were isolated and in vitro transcription in isolated nuclei in the presence of alpha-[ $\left[{ }^{32} \mathrm{P}\right] \mathrm{UTP}$ was carried out as described in Methods. Analysis of transcription products was performed by hybridization to immobilized DNA on nylon membranes; visualization of the hybridized radiolabeled RNA was performed by autoradiography. DNA fragments on membranes

were v-myc (2.9-kb v-myc insert in pBR322), pJEM120 (gamma globin-beta globin intergenic DNA containing repetitive Alu sequences), C6 1.8 Bam (beta-globin cDNA), and a 1-kb Pst-Xba fragment of the $\gamma$-actin gene. C-myc transcription decreases dramatically. Alu transcripts remain approximately the same, and hybridization to globin fragments is entirely negative, ruling out nonspecific binding. $\gamma$-actin transcripts decrease somewhat, but much less so than c-myc.

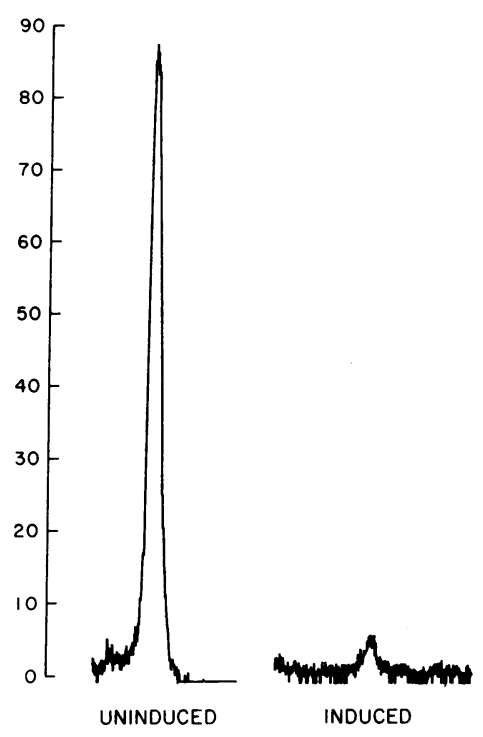

Figure 3. Densitometric analysis of c-myc autoradiograph. A 14-fold reduction in c-myc transcripts occurs with induced maturation.

determination of transcript half-life with actinomycin $\mathrm{D}$ chase experiments is impossible. Thus, using previous kinetic studies, we selected a time point, $18 \mathrm{~h}$ after DMSO induction, at which we knew that c-myc expression had decreased but was still detectable. At this time point, c-myc appears to have a similarly

\section{UN HL-60 IN HL-60}

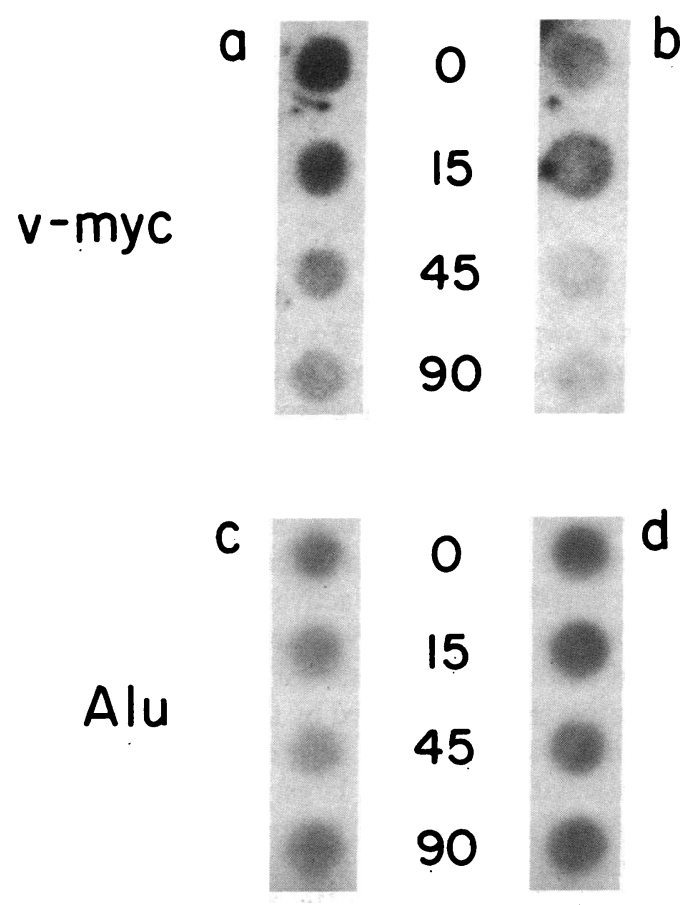

Figure 4. Cytoplasmic dot blot analysis of uninduced and induced HL-60 myc RNAs during an actinomycin chase. Uninduced and DMSO-induced HL-60 cells were incubated for $90 \mathrm{~min}$ in $10 \mu \mathrm{g} / \mathrm{ml}$ actinomycin D. At time points indicated, $3 \times 10^{7}$ cells were collected and cytoplasmic extracts prepared as described in Methods. Extracts were spotted on nitrocellulose and hybridized to a nick-translated v$m y c$ probe $(a, b)$. The same blots were then washed and rehybridized to an Alu probe as a control $(c, d)$. 

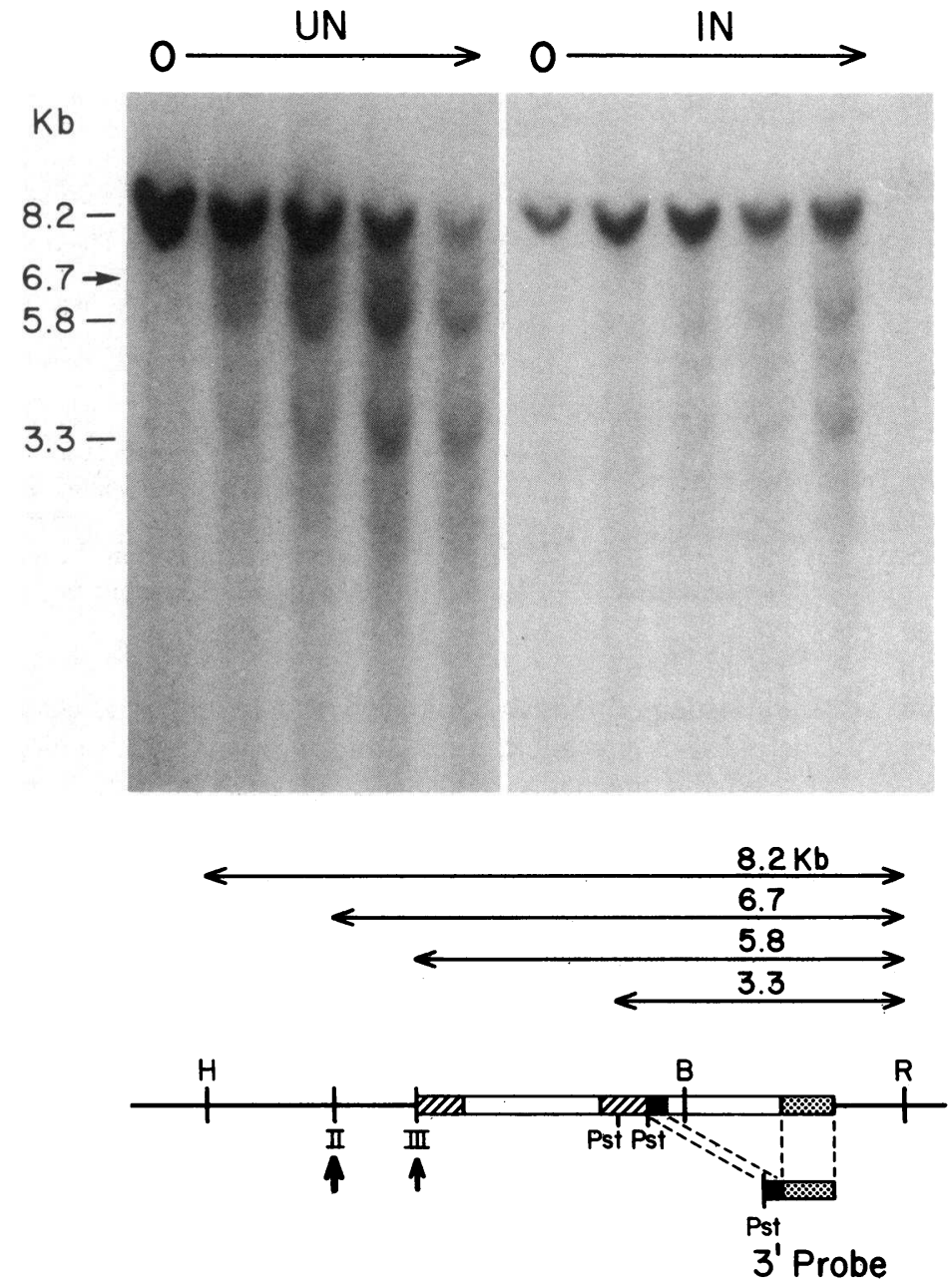

Figure 5. Location of DNAse I hypersensitive sites in the 5' flanking region of the c-myc gene in HL-60 cells. $(A)$ Following DNAse I digestion of uninduced and induced HL-60 nuclei, (direction of increasing DNAse I digestion indicated by arrow above each blot), DNA is purified, redigested with Eco RI and Hind III, and blot hybridized to the probe shown (cDNA extending from $3^{\prime}$ Pst site in second exon, through third exon). The 8.2-kb parent band and subbands are shown on the map. The 6.7-kb band, corresponding to hypersensitive site II, is unique to the uninduced cells. No band corresponding to site I (see text) is seen, since the Hind III site is internal to it. $(B) \mathrm{Bgl}$ II digest blot hybridized to a probe consisting of the first exon and 20 basepairs of second exon to ( $5^{\prime}$ Pst site). The 5.9-kb parent band and subbands generated are shown on the map and confirm the sites assigned above. The 3.3-kb band is unique to uninduced nuclei; induced lanes, purposely overloaded to search for this band, do not show it. $(C)$ Eco RI digest blot hybridized to probe described in $(A)$. The 12.8-kb parent band and subbands are shown on map. Note that use of this probe, located in the extreme $3^{\prime}$ portion of the Eco RI fragment, allows unequivocal assignment of hypersensitive sites (indirect end labeling technique). Again, note the disappearance with induction of the $6.7-\mathrm{kb}$ band. All blots were run with marker lanes. Bold arrows on maps indicate the site unique to uninduced nuclei. R, Eco RI; B, Bgl II; H, Hind III. short half-life, as shown in Fig. $4 b$. To demonstrate that the decreased signals did not merely reflect decreased RNA recovery after addition of actinomycin D, the same filters were washed and rehybridized to an Alu probe. These results are shown in Fig. 4, $c$ and $d$.

Loss of a c-myc region hypersensitive site with gene inactivation. DNAse I hypersensitive sites in the chromatin surrounding gene domains correlate well with active transcription of the nearby genes $(17,18)$. Hypersensitive sites are probably loci where interaction between specific effector proteins and DNA occur. Hypersensitive sites are detected by the ability to DNAse I to introduce double-stranded cuts into chromosomal DNA under conditions leaving bulk DNA largely intact. These sites are detected as loss of parent bands, depending on the probes used and restriction digests chosen, and/or generation of new subbands on Southern blots $(19,20)$. We have studied the hypersensitive sites in the $5^{\prime}$ flanking region of the $m y c$ gene. Nuclei isolated from uninduced and DMSO-induced HL-60 cells were digested with increasing concentrations of DNAse I. The purified DNA was then digested to completion with selected restriction endonucleases, electrophoresed on $0.8 \%$ agarose gels, and blotted onto nitrocellulose by the Southern procedure (15). Hypersen- sitive sites were detected as subbands using an indirect end labeling technique (21), as indicated in Fig. 5.

Fig. $5 \mathrm{~A}$ shows an Eco RI-Hind III digest of uninduced and induced HL-60 DNA hybridized to a cDNA probe that views the $c-m y c$ gene from its $3^{\prime}$ end. The lanes on each blot represent increasing concentrations of DNAse (left to right) beginning with 0 (no DNAse treatment). In each case, the 0 lanes show the 8.2$\mathrm{kb}$ parent band. As the degree of DNAse digestion increases, 5.8-kb and 3.3-kb subbands are generated in both uninduced and induced nuclei. The most interesting subband was a $6.7-\mathrm{kb}$ band, mapping to hypersensitive site II (shown on map in Fig. $5 \mathrm{~A}$ ), which was present only in the uninduced nuclei. A Bgl II digest (Fig. $5 B$ ), probed with a $5^{\prime}$ specific cDNA sequence, confirms the location of the hypersensitive sites in the $5^{\prime}$ flanking region and again shows that site II (represented in this case by the 3.3-kb subband) is unique to the uninduced nuclei.

Given the probes and restriction enzymes used, the hypersensitive sites assigned on the maps in Fig. 5, $A$ and $B$ are internally consistent but not unequivocal. To permit unequivocal assignment of sites, an Eco RI digest of DNAse-treated uninduced nuclei was probed with the $3^{\prime}$ probe shown in Fig. $5 C$. The subbands shown here, $8.2,6.7$, and $5.8 \mathrm{~kb}$, must have been 
B
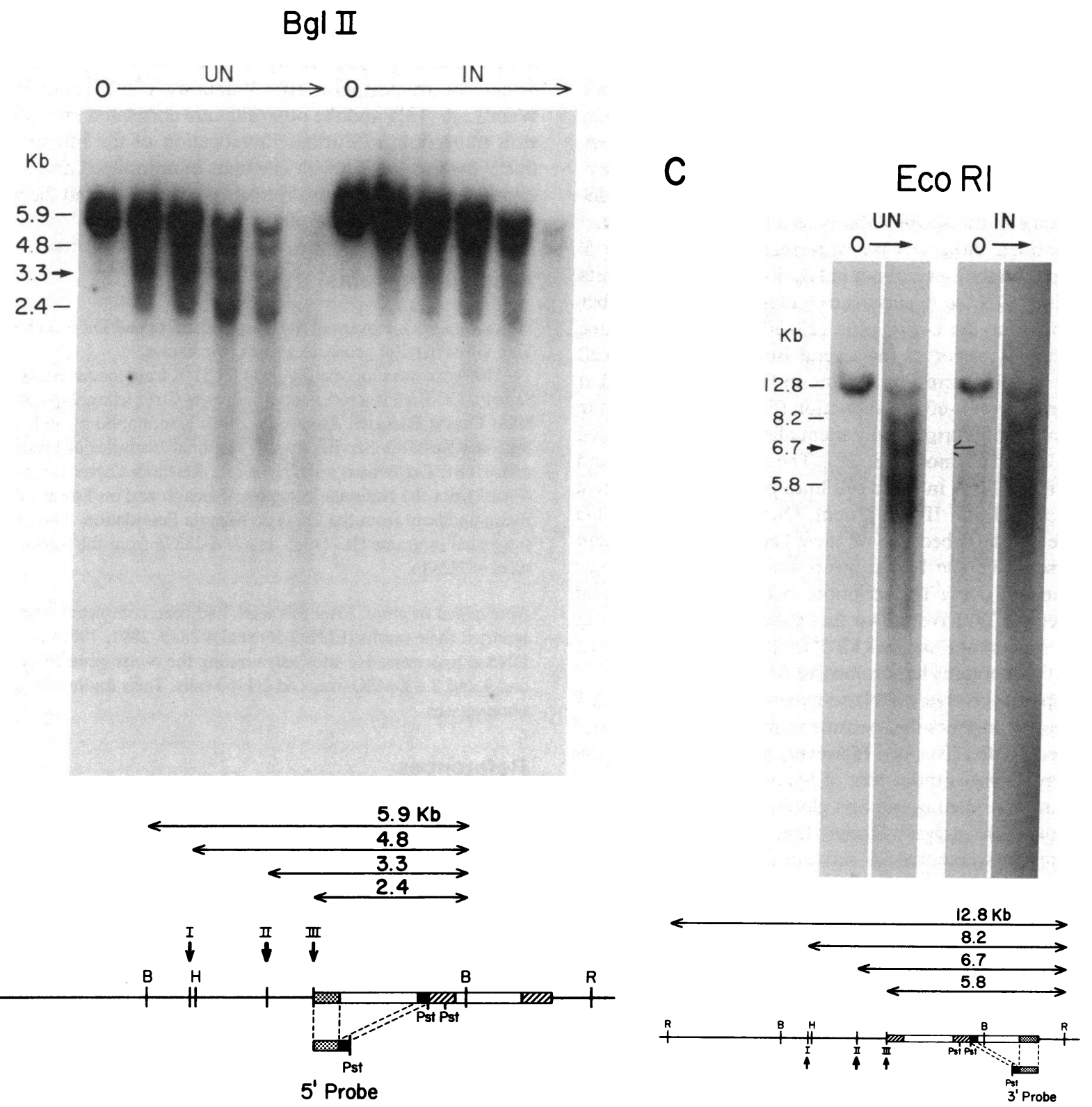

Figure 5 (Continued)

generated by the combination of a DNAse cut on the $5^{\prime}$ end and an Eco RI cut on the $3^{\prime}$ end. Subbands generated in the opposite way, an Eco RI cut on the $5^{\prime}$ end and a DNAse cut on the $3^{\prime}$ end, would be undetectable with the probe used, because a cleavage would necessarily occur between the $3^{\prime}$ probe and the $5^{\prime}$ Eco RI restriction site. The hypersensitive sites shown here confirm definitively those made previously. The induced blot in Fig. $5 C$ agains shows the characteristic loss of the $6.7-\mathrm{kb}$ band corresponding to hypersensitive site II.

In some blots shown in Fig. 5, a very faint subband mapping to hypersensitive site II can be seen in the lanes derived from induced cells. This is most likely due to the fact that DMSO induction results in induction of only $\sim 80 \%$ of the cells. The remaining uninduced cells are the likely source of these faint subbands. In Fig. $5 B$, the induced lanes have been purposely overloaded, but the 3.3-kb band is hardly detectable. An alter- native hypothesis is that hypersensitive site II is lost in only some of the copies of the amplified $m y c$ gene during induced maturation.

\section{Discussion}

Our results indicate that the decline in c-myc mRNA that occurs upon induction of HL-60 cells is mediated at the transcriptional level. Repression of transcription correlated well with selective loss of one of the three DNAse hypersensitive sites present in the $5^{\prime}$ flanking region of the $c-m y c$ gene. In agreement with others (22), we found that c-myc mRNA is highly unstable, having a half-life of $<20 \mathrm{~min}$; stability did not appear to change significantly after induction. Thus, although examples exist in which both transcriptional regulation and altered mRNA stability contribute to changes in mRNA level (23-25), the decline in c-myc 
mRNA in this case is mediated almost entirely at the transcriptional level. These results differ from those previously reported by Dani et al. for regulation of $m y c$ expression in interferontreated Daudi cells (26) and by the same group for growth factorstimulated Chinese hamster lung fibroblasts (27). This group found that in these cell lines, changes in steady state $m y c$ mRNA were accounted for primarily by changes in transcript stability. The basis for these differences is not clear. We observed no detectable change in transcript stability as a result of induction.

We identified three DNAse hypersensitive sites in the $5^{\prime}$ flanking region in the c-myc genes in HL-60 cells. Several reports have described DNAse hypersensitive sites varying in number and location near the c-myc gene (28-30). Our results agree closely with those reported for several Burkitt lymphoma cell lines $(28,29)$. It is interesting to note in fact, that the site that disappeared upon HL-60 cell induction (Fig. 5) is the same site absent from the transcriptionally silent allele in two Burkitt cell lines (BL 31 and Ramos) $(28,29)$. The nontranslocated and nontranscribed alleles in these cell lines possess hypersensitive site I, but sites II and III are absent. Our data emphasize the importance of site II because we have been able to document that hypersensitive site II disappears upon direct physiologic manipulation of c-myc transcription. It is also intriguing that Siebenlist et al. (29) have shown that a binding site for nuclear proteins is present at a site $\sim 1 \mathrm{~kb} 5^{\prime}$ to the first exon of c-myc, a location that contains hypersensitive site II.

The appearance of new DNAse-hypersensitive sites in the $5^{\prime}$ flanking regions of genes that become transcriptionally activated is well documented (31-36). However, gene inactivation has been accomplished without loss of hypersensitive sites in, for example, chicken vitellogenin and globin gene systems $(32,35$, 37). Such examples suggest strongly that certain hypersensitive sites may reflect a potential for active transcription rather than the state of actual transcription itself (35).

The results we present here represent one of only a few examples in which inactivation of transcription correlates with specific loss of a DNAse I hypersensitive site. Interpretation of changes in hypersensitive sites in many of these other systems is clouded by the concurrent rapid expansion and selection of different cell populations that also ensue upon manipulation of the experimental system. For example, the changes in globin chromatin accompanying the switch from embryonic or fetal to adult (37) globin gene activity in erythroid cells is probably mediated more by changes in the relative numbers of primitive (fetal) and definitive (adult) erythroid cells at different developmental stages than in intracellular chromatin configuration (20).

Specific loss of hypersensitive sites has been documented in two hormone-dependent systems, vitellogenin in chicken liver (32), and ovalbumin in chick oviduct (33). In each case, there are several DNAse-hypersensitive sites present when the gene is transcriptionally active, but only one disappears upon withdrawal of the hormone. The site that disappears has been postulated to interact with the hormone itself or its receptor. Our data suggest that HL-60 cells are unique in that they show disappearance of a specific DNAse hypersensitive site upon induction of terminal differentiation.

In summary, we have shown that the decline in c-myc gene expression occurring upon induction of HL-60 cells is mediated by a loss of transcriptional activity that correlates well with the disappearance of one of three preexistent DNAse hypersensitive sites. The other two sites persist. Our results suggest strongly that at least two distinct classes of hypersensitive sites exist in human hematopoietic cell lines. One is necessary but not sufficient for transcription (the "memory effect" described by Weintraub [13]), and the other sites are correlated more directly with transcription. Further investigation of the interaction of this $5^{\prime}$ flanking region with elements of uninduced and induced HL-60 nuclei should provide more information about the process of induced differentiation in leukemia cell lines.

\section{Acknowledgments}

We thank Dr. G. Rovera of the Wistar Institute and Dr. P. Lebowitz of Yale University for generous gifts of $m y c$ clones.

This work was supported by grant IN-31-X from the American Cancer Society. Dr. High is a recipient of a Brown-Coxe fellowship and a Swebilius Cancer Research Award. Dr. Stolle is supported by an individual National Research Service Award, National Institutes of Health grant AM-07681. Dr. Benz is a recipient of a Research Career Development Award from the National Institutes of Health and an Edward Paradiso Research Grant from the Cooley's Anemia Foundation. This work was supported by grants HL-24385 and AM-28376 from the National Institutes of Health.

Note added in proof. After this work had been completed, Dyson et al. reported their results (EMBO Journal 4:2885-2891, 1985) in mapping DNAse hypersensitive sites surrounding the c-myc gene in uninduced and 4 and $8 \mathrm{~d}$ DMSO-induced HL-60 cells. Their findings support our observations.

\section{References}

1. Collins, S. J., R. C. Gallo, and R. E. Gallagher. 1977. Continuous growth and differentiation of human myeloid leukaemia cells in suspension culture. Nature (Lond.). 270:347-349.

2. Collins, S. J., F. W. Ruscetti, R. E. Gallagher, and R. C. Gallo. 1978. Terminal differentiation of human promyelocytic leukemia cells induced by dimethyl sulfoxide and other polar compounds. Proc. Natl. Acad. Sci. USA. 75:2458-2462.

3. Haberman, E., and M. Callahan. 1979. Induction of terminal differentiation in human promyelocytic leukemia cells by tumor-promoting agents. Proc. Natl. Acad. Sci. USA. 76:1293-1297.

4. Westin, E. H., F. Wong-Staal, E. P. Gelmann, R. Della Favera, T. S. Papas, J. A. Lautenberger, E. Allessandra, E. P. Reddy, S. R. Tronick, S. A. Aaronson, and R. C. Gallo. 1982. Expression of cellular homologues of retroviral onc genes in human hematopoietic cells. Proc. Natl. Acad. Sci. USA. 79:2490-2494.

5. Dalla Favera, R., E. P. Gelman, S. Martinotti, G. Franchini, T. S. Papas, R. C. Gallo, and F. Wong-Staal. 1982. Cloning and characterization of different human sequences related to the onc gene ( $\mathrm{v}$ myc) of avian myelocytomatosis virus (MCP29). Proc. Natl. Acad. Sci. USA. 79:6497-6501.

6. Dalla Favera, R., F. Wong-Staal, and R. C. Gallo. 1982. Onc gene amplification in promyelocytic leukemia cell line HL-60 and primary leukaemic cells of the same patient. Nature (Lond.). 299:61-63.

7. Watt, R., L. W. Stanton, K. B. Marcu, R. C. Gallo, C. M. Croce, and G. Rovera. 1983. Nucleotide sequence of cloned cDNA of human c-myc oncogene. Nature (Lond.). 303:725-728.

8. Takeshita, K., B. G. Forget, A. L. Scarpa, and E. J. Benz, Jr. 1984. Intranuclear defect in beta-globin mRNA accumulation due to a premature translation termination codon. Blood. 64:13-22.

9. Gunning, P., P. Ponte, H. Okayama, J. Engel, H. Blau, and L. Kedes. 1983. Isolation and characterization of full-length cDNA clones for human $\alpha \beta$ and $\gamma$ actin mRNAs: skeletal but not cytoplasmic actins have an amino terminal cysteine that is subsequently removed. $\mathrm{Mol}$. Cell. Biol. 3:787-795. 
10. White, B. A., and F. C. Bancroft. 1982. Cytoplasmic dot hybridization. J. Biol. Chem. 257:8569-8572.

11. Thomas, P. 1980. Hybridization of denatured RNA and small DNA fragments transferred to nitrocellulose. Proc. Natl. Acad. Sci. USA. 77:5201-5202.

12. Mory, Y. Y., and M. L. Gefter. 1977. Synthesis of messenger RNA-like molecules in isolated myeloma nuclei. Nucl. Acids Res. 4: 1739-1757.

13. Linial, M., N. Gunderson, and M. Groudine. 1985. Enhanced transcription of c-myc in bursal lymphoma cells requires continuous protein synthesis. Science (Wash. DC). 230:1126-1132.

14. Maniatis, T., E. F. Fritsch, and J. Sambrook. 1982. Molecular Cloning: A Laboratory Manual. Cold Spring Harbor Laboratory, Cold Spring Harbor, NY. 458-459.

15. Southern, E. M. 1975. Detection of specific sequences among DNA fragments separated by gel electrophoresis. J. Mol. Biol. 98:503517.

16. Maniatis, T., S. G. Kee, A. Efstratiadis, and F. C. Kafatos. 1976. Amplification and characterization of a beta-globin gene synthesized in vitro. Cell. 8:163-182.

17. Elgin, S. C. R. 1984. Anatomy of hypersensitive sites. Nature (Lond.). 309:213-214.

18. Weisbrod, S. 1981. Active chromatin. Nature (Lond.). 297:289295.

19. Weintraub, H., and M. Groudine. 1976. Chromosomal subunits in active genes have an altered conformation. Science (Wash. DC). 193: 848-853.

20. Weintraub, H., A. Larsen, and M. Groudine. 1981. Alpha-globin gene switching during the development of chicken embryos: expression and chromosome structure. Cell. 24:333-344.

21. Wu, C. 1980. The $5^{\prime}$ ends of Drosophilia heat shock genes in chromatin are hypersensitive to DNA'ase I. Nature (Lond.). 286:854860 .

22. Dani, C., J. M. Blanchard, M. Piechuczyk, S. El Sabouty, L. Marty, and P. Jeanteur. 1984. Extreme instability of myc mRNA in normal and transformed human cells. Proc. Natl. Acad. Sci. USA. 81: 7046-7050.

23. Darnell, J. E., Jr. 1982. Variety in the level of gene control in eukaryotic cells. Nature (Lond.). 297:365-371.

24. Guyette, W. A., R. J. Matusik, and J. M. Rosen. 1979. Prolactinmediated transcriptional control of casein gene expression. Cell. 17:10131023.

25. Wiskocil, R., P. Bensky, R. F. Goldberger, J. I. Gordon, and
R. G. Deeley. 1980. Coordinate regulation of two estrogen-dependent genes in avian liver. Proc. Natl. Acad. Sci. USA. 77:4474-4478.

26. Dani, C., N. Mechti, M. Piechaczyk, B. Ledleu, P. Jeanteur, and J. M. Blanchard. 1985. Increased rate of degradation of c-myc mRNA in interferon-treated Daudi cells. Proc. Natl. Acad. Sci. USA. 82:48964899.

27. Blanchard, J. M., M. Piechaczyk, C. Dani, J. Chambard, A. Franchi, J. Pouyssegur, and P. Jeanteur. 1985. C-myc gene is transcribed at high rate in $\mathrm{G}_{0}$-arrested fibroblasts and is post-transcriptionally regulated in response to growth factors. Nature (Lond.). 317:443-445.

28. Dyson, P. J., and T. H. Rabbits. 1985. Chromatin structure around the $c m y c$ gene in Burkitt lymphomas with upstream and downstream translocation points. Proc. Natl. Acad. Sci. USA. 82:1984-1988.

29. Siebenlist, U., L. Henninghausen, J. Battey, and P. Leder. 1984. Putative regulatory region of the c-myc gene in Burkitt lymphoma. Cell. 37:381-391.

30. Tuan, D., and I. M. London. 1984. Mapping of DNAse I hypersensitive sites in the upstream DNA of human embryonic globin gene in K562 leukemia cells. Proc. Natl. Acad. Sci. USA. 81:2718-2722.

31. Balcarek, J. M., and F. A. McMorris. 1983. DNAse I hypersensitive sites of globin genes of uninduced Friend erythroleukemic cells and changes during induction with dimethyl sulfoxide. J. Biol. Chem. 258:10622-10628.

32. Burch, J. B. E., and H. Weintraub. 1983. Temporal order of chromatin structural changes associated with activation of the major chicken vitellogenin gene. Cell. 33:65-76.

33. Fritton, H. P., T. Igo-Kemenes, J. Nowock, U. Strech-Jurk, M. Thiesen, and A. E. Sippel. 1984. Alternative sets of DNAse I-hypersensitive sites characterize the various functional states of the chicken lysozyme gene. Nature (Lond.). 311:163-165.

34. McGhee, J. D., W. I. Wood, M. Dolan, J. D. Engel, and G. Felsenfeld. 1981. A 200 base pair region at the $5^{\prime}$ terminus of the rat preproinsulin II gene. Proc. Natl. Acad. Sci. USA. 78:1577-1580.

35. Stalder, J., A. Larsen, J. D. Engel, M. Dolan, M. Groudine, and H. Weintraub. 1980. Tissue-specific DNA cleavages in the globin chromatin domain introduced by DNA'ase I. Cell. 20:451-460.

36. Wu, L., and W. Gilbert. 1981. Tissue-specific exposure of chromatin structure at the $5^{\prime}$ terminus of the rat preproinsulin II gene. Proc. Natl. Acad. Sci. USA. 78:1577-1580.

37. Groudine, M., T. Kohwi-Shigematsu, R. Gelinas, G. Stamatoyannopoulos, and T. Papayannopoulos. 1983. Human fetal to adult hemoglobin switching; changes in chromatin structure of the beta-globin gene locus. Proc. Natl. Acad. Sci. USA. 80:7551-7555. 